\title{
The effect of heavy metals and other environmental conditions on the anaerobic phosphate metabolism of Acinetobacter johnsonii
}

\author{
Christopher D. Boswell, $\nmid$ R. Elaine Dick $\ddagger$ and Lynne E. Macaskie
}

Author for correspondence: Lynne E. Macaskie. Tel: +44 121414 5889. Fax: +44 1214146557. e-mail: l.e.macaskie@bham.ac.uk

School of Biological

Sciences, The University of Birmingham, Edgbaston, Birmingham B15 2TT, UK

\begin{abstract}
A strain of Acinetobacter with potential for bioremediation of heavy metalcontaminated waters was isolated from a wastewater-treatment plant operating an enhanced biological phosphate removal process. NMR and extractive methods showed that polyphosphate accumulated aerobically was degraded under anaerobic conditions both in the presence and absence of cadmium or uranium (0.2-0.5 mM). NMR showed that free phosphate was formed at the expense of polyphosphate, and an extractive technique indicated that this reaction could be stimulated by the presence of $\mathrm{UO}_{2}^{2+}$ under these conditions. Energy-dispersive X-ray microanalysis demonstrated that only cadmium could enter the cells, and co-localized with intra-cellular granules containing phosphate and other divalent metals. The effects of other environmental parameters on the anaerobic phosphate metabolism were also investigated. Between pH 5.5 and 8.0, phosphate release increased with increasing $\mathrm{pH}$. Between $4{ }^{\circ} \mathrm{C}$ and $37^{\circ} \mathrm{C}$, phosphate release increased with increasing temperature. The presence of nitrate at concentrations of $10 \mathrm{mM}$ and above inhibited anoxic phosphate release, but supplying tungstate in the growth medium prior to anoxic incubation reduced the production of active nitrate reductase and alleviated this effect.
\end{abstract}

Keywords: Acinetobacter sp., polyphosphate, heavy metal, toxicity

\section{INTRODUCTION}

Acinetobacter spp. have been implicated in enhanced biological phosphate removal (EBPR) in wastewatertreatment plants operating these processes. The basis for this is their isolation from such plants (Fuhs \& Chen, 1975; Barnard, 1976; Beacham, 1992) and the demonstration of the ability of certain strains to take up, store, then release inorganic phosphate $(\mathrm{Pi})$ under the appropriate conditions (van Groenestijn et al., 1985, 1989). Recent studies (Wagner et al., 1994a, b; Bond et

\footnotetext{
†Present address: School of Chemical Engineering, The University of
} Birmingham, Birmingham B15 2TT, UK.

¥Present address: QUESTOR Centre/Department of Chemical Engineering, The Queen's University of Belfast, David Keir Building, Stranmillis Road, Belfast BT9 5AG, Northern Ireland.

Abbreviations: EPBR, enhanced biological phosphate removal; EDAX, energy-dispersive $\mathrm{X}$-ray micro-analysis; MSM, minimal salts medium; $\mathrm{Pi}$ inorganic phosphate; polyP, polyphosphate; TEM, transmission electron microscopy. al., 1995; Christensson et al., 1998) have demonstrated that Acinetobacter spp. are not necessarily the principal organisms effecting EBPR and that members of the Rhodocyclus group may have a greater role in the process than previously thought. However, Acinetobacter spp. formed a significant proportion of polyphosphate (polyP)-accumulating organisms isolated from activated sludge in our own studies (C. D. Boswell \& R. E. Dick, unpublished). The isolate used in our studies represents Acinetobacter spp. from activated sludge capable of phosphate cycling and which may effect EBPR in at least some wastewater-treatment processes.

Aerobically, some Acinetobacter spp. can accumulate phosphate as polyP (Kornberg, 1995). Subsequent exposure to anaerobic conditions promotes polyP degradation with concomitant release of phosphate into the medium. This release has been coupled to bio-precipitation of heavy metals as cell-bound metal phosphates (Boswell et al., 1998) and could provide a novel 
approach to the co-treatment of phosphate- and heavy metal-contaminated wastewaters where the concentration of metal and phosphate is too low to exceed the solubility product of the metal phosphate(s) in the bulk solution. Here, localized phosphate release in close proximity to nucleation sites on the cells promotes the bio-crystallization of metals as $\mathrm{MHPO}_{4}(\mathrm{M}$, metal cation; Dick et al., 1995).

In addition to the toxicity of heavy metals, other cocontaminants and various environmental factors may affect cellular metabolism and polyP degradation/Pi release. This study aims to identify some parameters which may be critical both to EBPR processes and to Acinetobacter-based bioremediation systems.

Evaluation of polyP metabolism is difficult in the presence of heavy metals: precipitation of $\mathrm{Pi}$ as metal phosphate prevents direct measurement of phosphate release. Extraction and quantification of residual polyPs was used, therefore, as an evaluation criterion in conjunction with ${ }^{31}$ P-NMR to investigate the effect of $\mathrm{Cd}^{2+}$ and $\mathrm{UO}_{2}^{2+}$ on anaerobic phosphate metabolism. The cations were used at concentrations in the range which had previously been found to exhibit toxic effects on this organism (Boswell et al., 1998).

\section{METHODS}

Organism, growth conditions and preparation of cells. A strain of Acinetobacter johnsonii, designated 'M45' was isolated on minimal salts agar (see below) from a wastewatertreatment plant (Severn Trent pilot wastewater-treatment plant, Milcote, Warwickshire, UK) operating an EBPR process. The isolate was selected for its polyP-accumulating properties on the basis of a positive reaction to the Neisser stain (Gurr, 1963) and was identified using the Analytical Profile Index for non-enteric bacteria (API NE) kit (bioMérieux), negative Gram reaction and non-motile, coccoid morphology (Towner et al., 1991). The strain was maintained on agar plates of minimal salts medium (below) solidified with $1.5 \%(\mathrm{w} / \mathrm{v})$ granulated agar (Becton Dickinson). Plates were stored at $4{ }^{\circ} \mathrm{C}$ and subcultured every two weeks.

Aerobic batch cultures ( 170 r.p.m.) and phosphate-uptake tests used a defined minimal salts medium (MSM) in $20 \mathrm{mM}$ MOPS/NaOH (pH7.0;50 ml) containing the following components per litre: sodium acetate (trihydrate), $20 \mathrm{~g}$; $\left(\mathrm{NH}_{4}\right)_{2} \mathrm{SO}_{4}, 1.5 \mathrm{~g} ; \mathrm{MgSO}_{4} .7 \mathrm{H}_{2} \mathrm{O}, 0.16 \mathrm{~g} ; \mathrm{CaCl}_{2} .2 \mathrm{H}_{2} \mathrm{O}$, $0.08 \mathrm{~g} ; \mathrm{KCl}, 0.6 \mathrm{~g} ; \mathrm{K}_{2} \mathrm{HPO}_{4}, 0.65 \mathrm{~g} ; \mathrm{EDTA}$ (disodium salt), $0.25 \mathrm{mg}$; trace elements solution, $1.0 \mathrm{ml}$ (containing per litre: $\mathrm{ZnSO}_{4} .7 \mathrm{H}_{2} \mathrm{O}, 10 \mathrm{mg} ; \mathrm{MnCl}_{2} .4 \mathrm{H}_{2} \mathrm{O}, 3 \mathrm{mg} ; \mathrm{H}_{3} \mathrm{BO}_{3}, 30 \mathrm{mg}$; $\mathrm{CoCl}_{2} \cdot 6 \mathrm{H}_{2} \mathrm{O}, 20 \mathrm{mg} ; \mathrm{CuCl}_{2} \cdot 6 \mathrm{H}_{2} \mathrm{O}, 1 \cdot 0 \mu \mathrm{g} ; \mathrm{NiCl}_{2} \cdot 6 \mathrm{H}_{2} \mathrm{O}$, $2 \mathrm{mg} ; \mathrm{Na}_{2} \mathrm{MoO}_{4} .2 \mathrm{H}_{2} \mathrm{O}, 3 \mathrm{mg}$ ).

Exposure of growing cells to heavy metals. Cells were grown to exponential phase $\left(\mathrm{OD}_{600} 0 \cdot 3\right)$ as above. At this point a concentrated $(10 \mathrm{mM})$, filter-sterilized stock solution of cadmium nitrate or uranyl nitrate was added as required to a final concentration of $0 \cdot 1 \mathrm{mM}$. Cultures and metal-unsupplemented controls were incubated for a further $2.5 \mathrm{~h}$ then sampled $(1.5 \mathrm{ml})$ for electron microscopy and energy-dispersive X-ray micro-analysis (EDAX).

Anaerobic phosphate-release experiments. Cells were pregrown aerobically $\left(50 \mathrm{ml}, 16 \mathrm{~h}, \mathrm{OD}_{600} 1 \cdot 5,30^{\circ} \mathrm{C}, 180\right.$ r.p.m.) and stored on ice. Cells were harvested by centrifugation, washed with ice-cold $0.85 \%(\mathrm{w} / \mathrm{v}) \mathrm{NaCl}$ and resuspended in the $\mathrm{NaCl}$ to $10 \%$ of the final working volume of the experiments. Aliquots of the concentrated cells $(1.0 \mathrm{ml}$ each) were placed in $10 \mathrm{ml}$ glass anaerobic bottles and $9.0 \mathrm{ml} 20 \mathrm{mM}$ MOPS/ $\mathrm{NaOH}, \mathrm{pH} 7.0$ (except where otherwise stated; see below) was added. Vials were sealed with butyl rubber caps and gassed with oxygen-free nitrogen (10 min) via a hypodermic needle. The needle was used to withdraw samples and the removed volume was simultaneously replaced with oxygen-free nitrogen via a second needle. Supernatants for analyses were produced by centrifugation $\left(12000 \mathrm{r} . \mathrm{p} . \mathrm{m} ., 4^{\circ} \mathrm{C}\right.$, MSE Micro Centaur) of culture samples. Cell pellets were stored at $-20^{\circ} \mathrm{C}$ prior to poly $\mathrm{P}$ analysis.

Detection of Pi and polyP using ${ }^{31} \mathbf{P}$-NMR. Cells were exposed to cadmium and uranium under anaerobic conditions by the addition of filter-sterilized stock solutions of either uranyl nitrate or cadmium nitrate to $0.2 \mathrm{mM}$ as appropriate immediately prior to anaerobic incubation as described above. For ${ }^{31} \mathrm{P}$-NMR spectroscopy, cells were harvested at the times shown in Fig. 1. Cell pellets or concentrates (e.g. OD ${ }_{600} 2.09$; $292 \mu \mathrm{g}$ protein $\mathrm{ml}^{-1}$ ) were kept on ice and analysed within 10 min of harvesting. NMR spectra were acquired on a Bruker AMX-400 spectrometer at a frequency of $161.98 \mathrm{MHz}$. The sweep width was $20 \mathrm{kHz}$ and spectra were acquired with a $4.5 \mu$ s pulse, $1.0 \mathrm{~s}$ acquisition time and $31.3 \mu$ s recycle delay. The standard was $85 \%(\mathrm{v} / \mathrm{v}) \mathrm{H}_{3} \mathrm{PO}_{4}$ and $\mathrm{D}_{2} \mathrm{O}$ was used as the field frequency lock via a capillary insert. In the case of uranyl, residual metal in the supernatant was analysed using arsenazo III (Tolley, 1993; Dick et al., 1995).

Extraction, purification and quantification of polyP fractions. The method of Clark et al. (1986) was used for polyP extraction and analysis, and was modified according to the method of Bayly et al. (1991), in which separation of polyPs from nucleic acids was not undertaken. To inhibit phosphatases, $100 \mathrm{mM} \mathrm{NaF}$ was added after each washing step to give a final concentration of $1.0 \mathrm{mM}$ (Rao et al., 1985) and samples were kept on ice between steps. The procedure, described below, produced three fractions: 1 , considered to contain short-chain or surface (periplasmic) polyPs; 2 , considered to contain long-chain soluble polyPs, and 3 , considered to contain long-chain granular polyPs as demonstrated previously by polyacrylamide gel electrophoresis (Clark et al., 1986). Cells were harvested by centrifugation (12000 r.p.m., $4{ }^{\circ} \mathrm{C}$, MSE Micro Centaur) in pre-weighed $1.5 \mathrm{ml}$ microcentrifuge tubes, washed with $0.85 \%(\mathrm{w} / \mathrm{v})$ sodium chloride and combined as appropriate to give pellets of $0.1 \mathrm{~g}$ wet weight of cells. Pellets were washed in $0.3 \mathrm{ml}$ ice cold trichloroacetic acid (TCA: $2 \%, w / v$, aq.). The retained supernatant was denoted 'Fraction 1'. The pellet was washed in $0.2 \mathrm{ml}$ ice cold $0.7 \%$ (w/v, aq.) TCA: $67 \%$ (v/v, aq.) acetone and the supernatant combined with Fraction 1 . The cell pellet was then washed in $0.25 \mathrm{ml}$ ice cold $67 \%$ (v/v, aq.) acetone then $0.25 \mathrm{ml} 2 \mathrm{mM}$ EDTA (sodium salt). The cell suspension in EDTA was neutralized to $\mathrm{pH} 7-8$ by the addition of $0.2 \mathrm{M} \mathrm{LiOH}$. Cells were harvested and the retained supernatant was denoted 'Fraction 2'. The residual pellet was washed in $0.25 \mathrm{ml} 2 \mathrm{mM}$ EDTA, neutralized to $\mathrm{pH} \mathrm{7-8}$ with $\mathrm{LiOH}$ as before, and an equal volume (approx. $0 \cdot 2 \mathrm{ml}$ ) of ice cold $1: 1(\mathrm{v} / \mathrm{v})$ phenol/chloroform was added, mixed thoroughly, then centrifuged for $10 \mathrm{~min}$ (12000 r.p.m., $4{ }^{\circ} \mathrm{C}$, MSE Micro Centaur). The aqueous layer was removed and denoted 'Fraction 3'.

PolyP was purified from each fraction by the addition of an equal volume of ice cold phenol/chloroform/isoamyl alcohol 
(25:24:1, saturated with $0 \cdot 1 \mathrm{M}$ ammonium acetate, $\mathrm{pH} 6 \cdot 5$ ), centrifugation as above and retention of the aqueous phase. This was followed by three successive extractions using icecold chloroform. The aqueous fraction was retained for polyP determination. Each of the polyP-containing fractions was hydrolysed separately by boiling $(15 \mathrm{~min})$ in an equal volume of $2 \mathrm{M} \mathrm{HCl}$. Samples were diluted as appropriate with distilled water and the ortho-phosphate content determined using the colorimetric (molybdenum blue) method modified from the method of Pierpoint (1957) (see below).

Electron microscopy and EDAX analysis. Samples ( $1 \mathrm{ml})$ were centrifuged (12000 r.p.m., Heraeus Sepatech Biofuge A, $10 \mathrm{~min}$, ambient temperature), fixed by resuspension in $2.5 \%$ $\mathrm{v} / \mathrm{v}$ aqeuous glutaraldehyde in $0 \cdot 1 \mathrm{M}$ sodium cacodylate buffer $(\mathrm{pH} 7 \cdot 2,1 \mathrm{~h})$, recentrifuged and resuspended in $0.85 \%(\mathrm{w} / \mathrm{v})$ $\mathrm{NaCl}$. Fixed samples were stored at $4{ }^{\circ} \mathrm{C}$ until use, centrifuged and resuspended in $1 \% \mathrm{w} / \mathrm{v}$ osmium tetroxide in $0.1 \mathrm{M}$ phosphate buffer ( $\mathrm{pH} 7 \cdot 2,1 \mathrm{~h}$ ), dehydrated progressively in an ethanol/water series (v/v: 70,90,100 and 100\%) and dried with $100 \%$ ethanol (15 min each step). Two 15 min washes in propylene preceded embedding in epoxy resin under vacuum $(20 \mathrm{~min})$. The resin was then left to polymerize $\left(24 \mathrm{~h}, 60^{\circ} \mathrm{C}\right)$. For EDAX analysis, sections $(100-150 \mathrm{~nm})$ were cut using a Reichart-Jung Ultracut $E$ microtome and placed onto a carbon-coated copper grid. Sections were viewed using a JEOL 120CX2 transmission electron microscope (accelerating voltage $100 \mathrm{kV}$ ) fitted with a Link ISI EDAX system (JEOL). The cells were probed in intracellular regions corresponding to electron-opaque areas, non-electron-opaque areas, cellwall regions and also in background areas in the intercellular resin. The limit of resolution of the EDAX microprobe was approximately $0 \cdot 1 \mu \mathrm{m}$. For routine transmission electron microscopy (TEM), $70 \mathrm{~nm}$ sections cut from the same block were viewed using a JEOL Ex transmission electron microscope (accelerating voltage $80 \mathrm{kV}$ ).

The effect of $\mathrm{pH}$, temperature and nitrate on anaerobic phosphate release. The following buffers were used $(20 \mathrm{mM})$ : MES/NaOH (pH 5.5, 6.0), PIPES/NaOH (pH 6.5), MOPS/ $\mathrm{NaOH}(\mathrm{pH} 7 \cdot 0,7 \cdot 5), \mathrm{HEPES} / \mathrm{NaOH}$ (pH 8.0). Experiments to test the effect of temperature and nitrate $(10$ and $100 \mathrm{mM}$ sodium nitrate) were in a background of $20 \mathrm{mM}$ MOPS/ $\mathrm{NaOH}, \mathrm{pH} 7 \cdot 0$; procedures were as above.

Preparation of nitrate reductase-deficient cells. Cells deficient in nitrate reduction were prepared by growth with tungstate, an analogue of molybdate which is required for the function of nitrate reductase (Stewart, 1988). Cells were incubated as described previously for aerobic phosphate uptake in MSM without molybdate but with filter-sterilized sodium tungstate (5 mM). Controls were grown in tungstate-unsupplemented MSM as described above. Tungstate-treated and control cells were harvested and incubated anoxically at $30^{\circ} \mathrm{C}$ as described above, with and without $10 \mathrm{mM}$ sodium nitrate. Samples were taken periodically for phosphate and nitrite analysis of supernatants. Residual nitrate reductase activity was quantified by analysis of nitrite formation.

Phosphate and nitrite analysis. Pi in culture supernatants was measured using the method of Pierpoint (1957), modified for use with $3 \mathrm{ml}$ micro-cuvettes (Sarstedt). Test or standard solution $(0.3 \mathrm{ml})$ distilled, deionized water $(1.0 \mathrm{ml}) 7.5 \%(\mathrm{w} / \mathrm{v}$ aq.) sodium molybdate mixed in a $2: 1(\mathrm{v} / \mathrm{v})$ ratio with $2.5 \mathrm{M}$ sulphuric acid $(0.6 \mathrm{ml}) 60 \%(\mathrm{w} / \mathrm{v}) \mathrm{SnCl}_{2}$ in concentrated $(11.8 \mathrm{M}) \mathrm{HCl}$, diluted $0.25 \%(\mathrm{v} / \mathrm{v})$ in $1 \mathrm{M} \mathrm{HCl}$ immediately prior to use $(0.4 \mathrm{ml})$ were mixed thoroughly and the $A_{720}$ determined.
For determination of nitrite in culture supernatants, a Griess (sulfanilamide/napthylenediamine dihydrochloride) reaction (Tomsett \& Garrett, 1980; modified for micro-cuvettes) was used : $25 \mu \mathrm{l}$ sample or standard solution was added to $1.85 \mathrm{ml}$ $1 \%(\mathrm{w} / \mathrm{v})$ sulphanilamide (Sigma) in $1.0 \mathrm{M} \mathrm{HCl}, 0.5 \mathrm{ml} 0.01 \%$ (w/v) naphthylenediamine dichlorohydride (Sigma) was added and the contents of the cuvette mixed well. After incubation ( $30 \mathrm{~min}, 15-20^{\circ} \mathrm{C}$ ), the $A_{540}$ was measured and compared to freshly prepared standards $(0 \cdot 1-5 \cdot 0 \mathrm{mM}$ sodium nitrite) in the appropriate medium.

\section{RESULTS}

\section{Mobilization of polyP in the presence of $\mathrm{Cd}^{2+}$ and $\mathrm{UO}_{2}^{2+}$}

PolyPs can be distinguished from Pi in vivo using ${ }^{31} \mathrm{P}-$ NMR due to the difference in the molecular environment of the ${ }^{31} \mathrm{P}$ atom in the two types of molecule (Suresh $e t$ al., 1986; Keasling \& Hupf, 1996). As described previously (Suresh et al., 1986), the polyP and Pi resonances were detected between -23 and -22 p.p.m., and between 2 and 3 p.p.m., respectively (Fig. 1a). Although at a relatively low signal-to-noise ratio, the disappearance of polyP from intact cells and the appearance of $\mathrm{Pi}$ was observed (Fig. 1b). A similar result was obtained in the presence of $\mathrm{UO}_{2}^{2+}$ (Fig. 1c) and $\mathrm{Cd}^{2+}$ (Fig. 1d). In control cells (Fig. 1b), polyP was still detectable after 1-2 $\mathrm{h}$ but following incubation with metals (Fig. 1c, d) polyP was not detectable after $1 \mathrm{~h}$, suggesting possible metal-promotion of polyP mobilization in the presence of metals. Variation in the linewidth and intensity of the polyP signal in the presence of $\mathrm{UO}_{2}^{2+}$ was observed; the paramagnetic uranium nucleus is known to quench the NMR signal (Tjissen \& van Steveninck, 1984), making quantitative analysis difficult.

Pi release was therefore also estimated in the absence and presence of $\mathrm{UO}_{2}^{2+}$. In the absence of $\mathrm{UO}_{2}^{2+}$, after 1 and $2 \mathrm{~h}$ incubation, the amount of Pi release was 0.104 $( \pm 0.013)$ and $0.253( \pm 0.013) \mathrm{mmol} \mathrm{l}^{-1}$ respectively. After 1 and $2 \mathrm{~h}$ incubation in the presence of $0.2 \mathrm{mM}$ $\mathrm{UO}_{2}^{2+}, \mathrm{Pi}$ release was $0.070( \pm 0.01)$ and $0.121( \pm 0.006)$ mmoll ${ }^{-1}$ respectively. Although the total Pi released was less in the presence of $\mathrm{UO}_{2}^{2+}$, assuming a molar ratio of $\mathrm{U}: \mathrm{P}$ of $1: 1$ in the precipitated $\mathrm{HUO}_{2} \mathrm{PO}_{4}$ (Dick et al., 1995), the accountable free Pi recovered in the supernatant after $1 \mathrm{~h}(0.070 \mathrm{mM})$, together with additional $\mathrm{Pi}$ accountable with the corresponding loss of $\mathrm{UO}_{2}^{2+}$ $(0.18 \mathrm{mM})$ made a total Pi release of $0.25 \mathrm{mM}$, i.e. the rate of polyP mobilization was approximately doubled in the presence of $0 \cdot 2 \mathrm{mM} \mathrm{UO}_{2}^{2+}$. By $2 \mathrm{~h}$ all of the uranyl ion was removed from solution.

\section{Extractive method for the determination of anaerobic polyP degradation in the presence of heavy metals}

${ }^{31}$ P-NMR spectroscopy is a useful technique for the study of phosphate species in vivo, but it is relatively insensitive and does not provide information on all polyP species present (Suresh et al., 1986). The extractive 
(a) PolyP standards
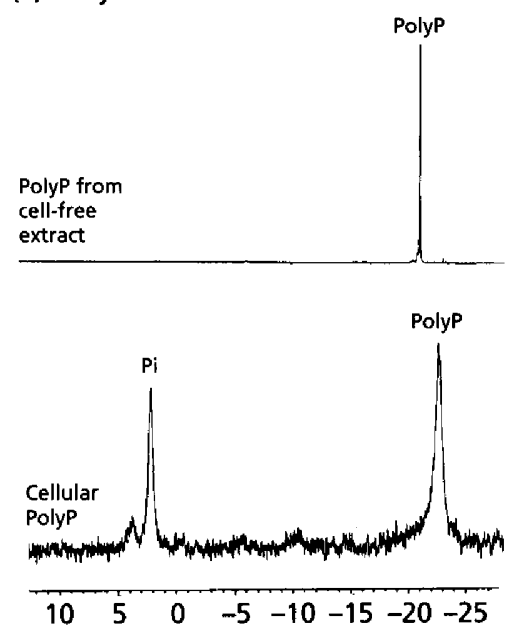

(d) Cadmium

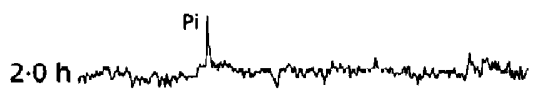

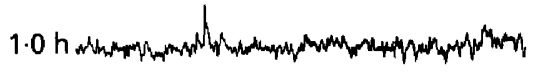

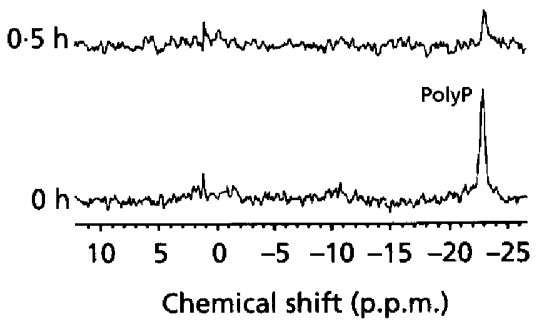

(b) Control

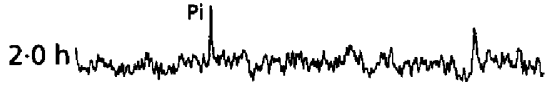

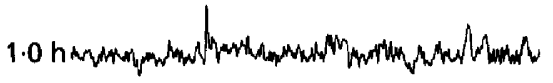

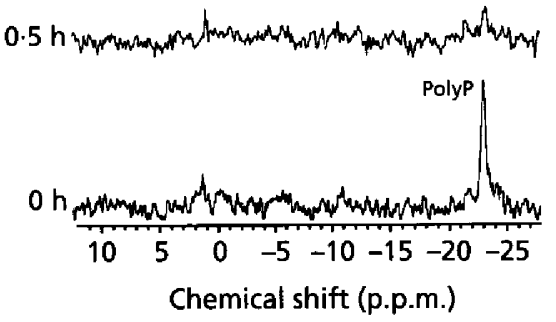

(c) Uranium

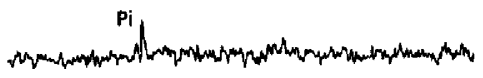

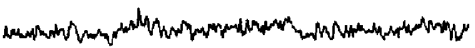

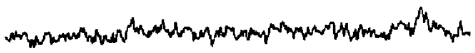

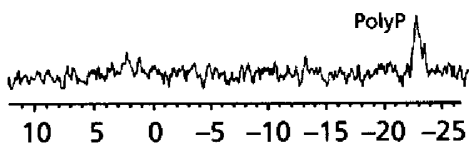

Fig. 1. ${ }^{31} \mathrm{P}-\mathrm{NMR}$ analysis. (a) Cell-free extract of polyP from $A$. johnsonii M45 prepared using the method of Clark et al. (1986) (top) and polyP in intact cells of A. johnsonii M45 (bottom). Intact cells were incubated anaerobically at $30^{\circ} \mathrm{C}$ in (b) buffer (20 mM MOPS/NaOH, pH 7.0) only; (c) buffer with $0.2 \mathrm{mM} \mathrm{UO} 2_{2}^{2+}$; (d) buffer with $0.2 \mathrm{mM} \mathrm{Cd}^{2+}$. The times indicate the incubation period prior to sampling.

method for measurement of cellular polyP (Fig. 2) showed that phosphate was present in each of the three fractions and that degradation of polyPs occurred during $2 \mathrm{~h}$ anaerobic incubation. Disappearance of phosphate from Fraction 1 (short-chain, periplasmic polyP) both in the presence and absence of $\mathrm{UO}_{2}^{2+}$ or $\mathrm{Cd}^{2+}$ was apparent. In both cases, less phosphate remained in Fraction 1 following incubation at the higher metal concentration $(0.5 \mathrm{mM})$ compared with the lower $(0.2 \mathrm{mM})$. Degradation of Fraction 1 was approximately $75 \%$ greater at $0.5 \mathrm{mM} \mathrm{UO}_{2}^{2+}$ than at $0.2 \mathrm{mM}$. In the case of $\mathrm{Cd}^{2+}$ this increase was approximately $35 \%$. A decrease in the phosphate content of Fraction 2 (long-chain, soluble polyP) over $2 \mathrm{~h}$ was observed for control cells and was enhanced in cells exposed to $0.2 \mathrm{mM}$ uranium, but there was no significant decrease in the phosphate content of Fraction 2 for cells exposed to cadmium at either concentration. Degradation of long-chain, granular polyP (Fraction 3) was only greater than the control in cells exposed to $0.5 \mathrm{mM}$ uranium (significant at $P=0.95$ ).
The increased hydrolysis of Fractions 1 and 3 in cells exposed to $0.5 \mathrm{mM} \mathrm{UO}_{2}^{2+}$ compared with the control was reflected in the greater overall degradation of polyP, whereas the inhibition of total polyP degradation by cadmium was observed (Fig. 2a). The total polyP analysis is shown in Table 1

Table 1. Contribution of each of three fractions to the total polyP content of $A$. johnsonii M45

Fractions were extracted and analysed according to the method of Clark et al. (1986) (see text). Percentages are shown as phosphate content \pm SEM and are from three experiments.

\begin{tabular}{|lc|}
\hline PolyP fraction & Percentage of total polyP \\
\hline 1 (Short chain, surface) & $9 \cdot 89 \pm 2 \cdot 19$ \\
2 (Long chain, soluble) & $52 \cdot 53 \pm 3 \cdot 07$ \\
3 (Long chain, granular) & $37 \cdot 58 \pm 4 \cdot 02$ \\
\hline
\end{tabular}



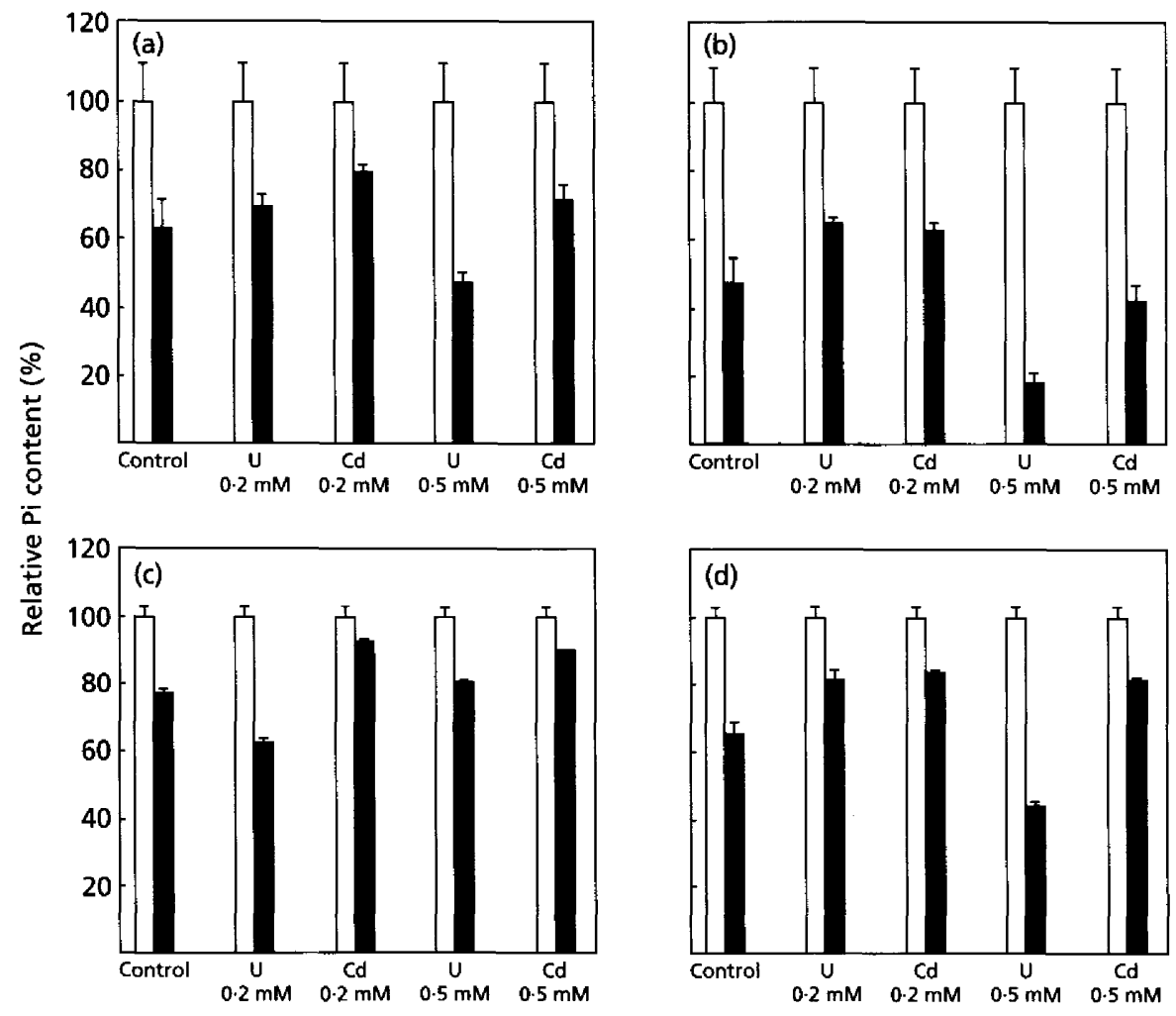

Fig. 2. Extraction and quantification of polyP in three fractions from A. johnsonii M45 immediately prior to (white) and following (black) $2 \mathrm{~h}$ anaerobic incubation (see Methods). (a) Total polyP. (b) Fraction 1, short-chain or surface (periplasmic) polyPs; (c) Fraction 2, long-chain soluble polyPs; (d) Fraction 3, long-chain granular polyPs. Error bars indicate SEM from three experiments. Data are expressed as percentage of the control value in each case.

\section{Electron microscopy and EDAX of heavy metal- exposed cells}

The growth of exponential-phase cells was inhibited by exposure to either $0.1 \mathrm{mM} \mathrm{Cd}^{2+}$ or to $0.1 \mathrm{mM} \mathrm{UO}_{2}^{2+}$ (Fig. 3a). Electron microscopy of cadmium-supplemented cells indicated the presence of intracellular, electron-opaque granules (Fig. 3c, arrows), with cadmium detected in the electron-opaque granules (EDAX data not shown) but not in the cell wall or the cytoplasm. In addition to cadmium, phosphorus, magnesium and calcium were detected in the granules (the copper signal was from the grid). Uranium was not detected in cell walls or within $\mathrm{UO}_{2}^{2+}$-exposed cells. Although electron-opaque granules were less apparent in uranium-challenged cells (Fig. 3), the cells, overall, contained intracellular phosphate. This confirmed that intracellular phosphorus is detectable within the limit of sensitivity of the EDAX technique, hence confirming the lack of intracellular uranium; other metals were clearly detectable at these concentrations (above).

\section{The effect of $\mathrm{pH}$, temperature and nitrate on anaerobic phosphate release}

A positive relationship between anaerobic $P i$ release and both increasing $\mathrm{pH}$ (Fig. 4a) and increasing temperature (Fig. 4b) was observed. The presence of nitrate (Fig. 4c) had an inhibitory effect on anaerobic phosphate release measured at concentrations of $10 \mathrm{mM}$ and above.

\section{The effect of nitrate on anoxic phosphate release by nitrate reductase-deficient cells}

PolyP mobilization is triggered by a shift to anaerobiosis; provision of nitrate as an alternative electron acceptor to $\mathrm{O}_{2}$ could inhibit this process. Using the nitrite assay described above, A. johnsonii M45 was found to convert nitrate to nitrite under anoxic conditions when an electron donor was provided. Further reduction of nitrite to gaseous $\mathrm{N}_{2}$ was not detected. Attempts to produce useful nitrate reductase-deficient mutants were unsuccessful. Nitrate reductase-negative mutants were generated by selection techniques based on chlorate resistance (Tomsett \& Garrett, 1980; Pascal et al., 1982) but none of these could accumulate phosphate to high levels. Instead, formation of functional nitrate reductase was prevented by out-competition of molybdate with tungstate. For cells which were not grown with tungstate which were subsequently incubated anoxically with $1.0 \mathrm{mM} \mathrm{KNO}$, the supernatant concentration of nitrite at 0,2 and $4 \mathrm{~h}$ was 0 , $0.320( \pm 0.025)$ and $0.658( \pm 0.035) \mathrm{mmol} \mathrm{1}^{-1}$, respectively. For cells grown with $5.0 \mathrm{mM}$ sodium tungstate, the corresponding concentrations of nitrite $(0,2$ and $4 \mathrm{~h})$ 

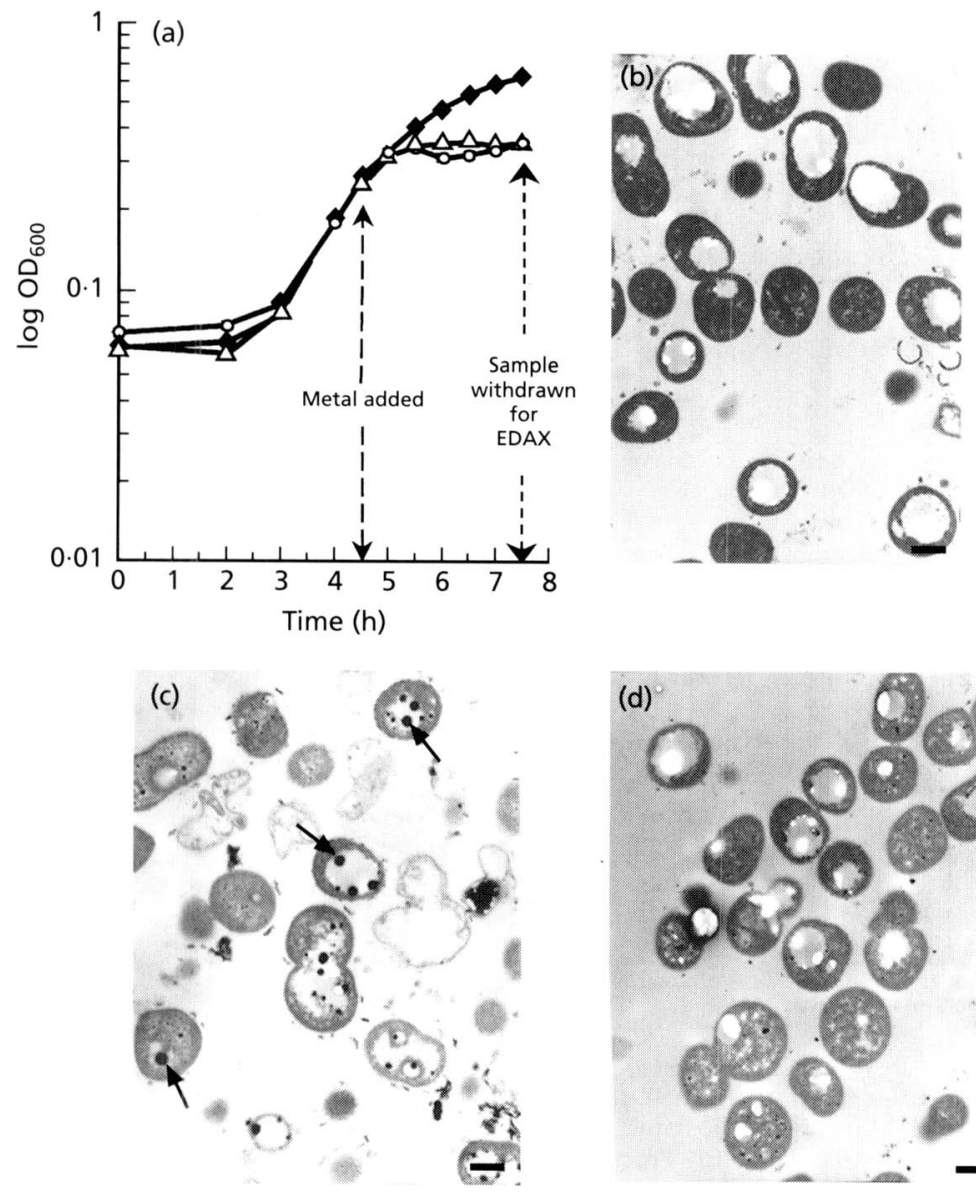

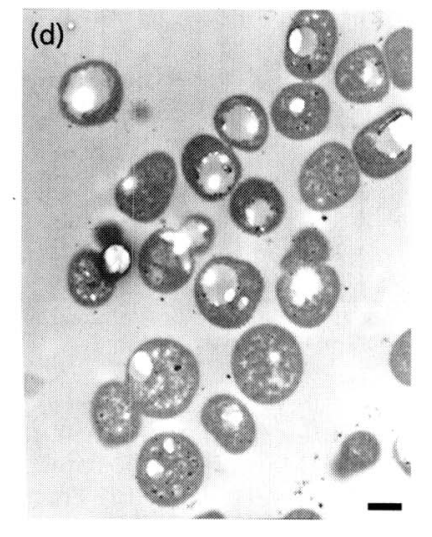

Fig. 3. (a) The effect of $0.1 \mathrm{mM} \mathrm{Cd}^{2+}(\triangle)$ and $0.1 \mathrm{mM} \mathrm{UO}_{2}^{2+}(O)$ on the growth of $A$. johnsonii M45 (control, $\bullet$, no added metal). Metals were added at the time indicated $\left(O D_{600} 0.3\right)$. Example fields from TEM are: (b) A. johnsonii incubated without heavy metal; (c) following $2.5 \mathrm{~h}$ incubation with $0.1 \mathrm{mM}$ $\mathrm{Cd}^{2+}$; (d) following $2.5 \mathrm{~h}$ incubation with $0.1 \mathrm{mM} \mathrm{UO}_{2}^{2+}$. Arrows in (c) indicate electron-opaque granules. Bar, $500 \mathrm{~nm}$. were $0,0.128( \pm 0.035)$ and $0.282( \pm 0.042) \mathrm{mmol} \mathrm{l}^{-1}$ respectively. Thus, compared with control (tungstate unsupplemented) cells, an (approx.) $50 \%$ reduction in the production of nitrite was observed in tungstategrown cells.

In separate experiments, for control cells, incubation in the presence of $10 \mathrm{mM}$ nitrate caused inhibition (approx. $50 \%$ ) of $\mathrm{Pi}$ release after $2 \mathrm{~h}$ anaerobic incubation and approximately $75 \%$ after $4 \mathrm{~h}$ (Fig. 5). $\mathrm{Pi}$ release by cells grown with tungstate was similar to that of the control cells in the absence of nitrate. Inhibition by nitrate of $\mathrm{Pi}$ release by these cells was not apparent after $2 \mathrm{~h}$, although approximately $50 \%$ inhibition of $\mathrm{Pi}$ release was observed after $4 \mathrm{~h}$.

\section{DISCUSSION}

According to the work of Suresh et al. (1986), only surface polyPs are accessible to ${ }^{31} \mathrm{P}-\mathrm{NMR}$. Following disappearance of the polyP signal in intact cells (as a result of polyP degradation), the signal could be restored by preparing cell-free extracts. In the present study, the NMR analysis (Fig. 1) should be compared with Fraction 1 obtained by the extractive method (Fig. 2). Both methods indicate that surface polyP is degraded both in the presence and absence of heavy metals. This is consistent with a study using flow cytometry and a membrane-impermeable nucleic acid stain, which showed that although the growth of Acinetobacter sp. exposed to submillimolar concentrations of $\mathrm{Cd}^{2+}$ or $\mathrm{UO}_{2}^{2+}$ for periods exceeding $2 \mathrm{~h}$ was inhibited, most cells remained intact (Boswell et al., 1998). The results of the methods for detection of polyP differ, however, in that NMR indicates that the rate of surface-polyP degradation is greater in the presence of $0.2 \mathrm{mM} \mathrm{UO}_{2}^{2+}$ than in the control (Fig. 1b, c) in accordance with assay of phosphate released (see above). From data obtained by the extractive method, the extent of surface-polyP degradation in the control was apparently greater than

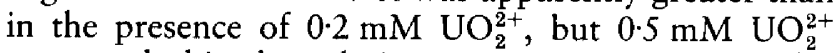
promoted this degradation (Fraction 1, Fig. 2a, b). Accurate evaluation of the extent of polyP degradation by ${ }^{31} \mathrm{P}-\mathrm{NMR}$ in the presence of $\mathrm{UO}_{2}^{2+}$ is difficult to assess because $\mathrm{UO}_{2}^{2+}$ quenches the NMR signal and has been used specifically for this purpose (Tijssen \& van Steveninck, 1984). The low sensitivity of ${ }^{31} \mathrm{P}-\mathrm{NMR}$ also makes accurate quantification difficult, but no residual polyP was detected after $1 \mathrm{~h}$ in uranium-treated cells (residual polyP was detected in control cells, Fig. 1b). The ${ }^{31} \mathrm{P}-\mathrm{NMR}$ data, taken together with the analysis of Fraction 1 from $0.5 \mathrm{mM} \mathrm{UO}_{2}^{2+}$-challenged cells (Fig. 2b) and direct assay of $\mathrm{Pi}$ suggest that $\mathrm{UO}_{2}^{2+}$ promotes the breakdown of surface polyP, as suggested previously in the case of $\mathrm{Cd}^{2+}$ (Suresh et al., 1986). In the present study, the evidence for such $\mathrm{Cd}^{2+}$ stimulation of surfacepolyP breakdown is not clear, as degradation is within 

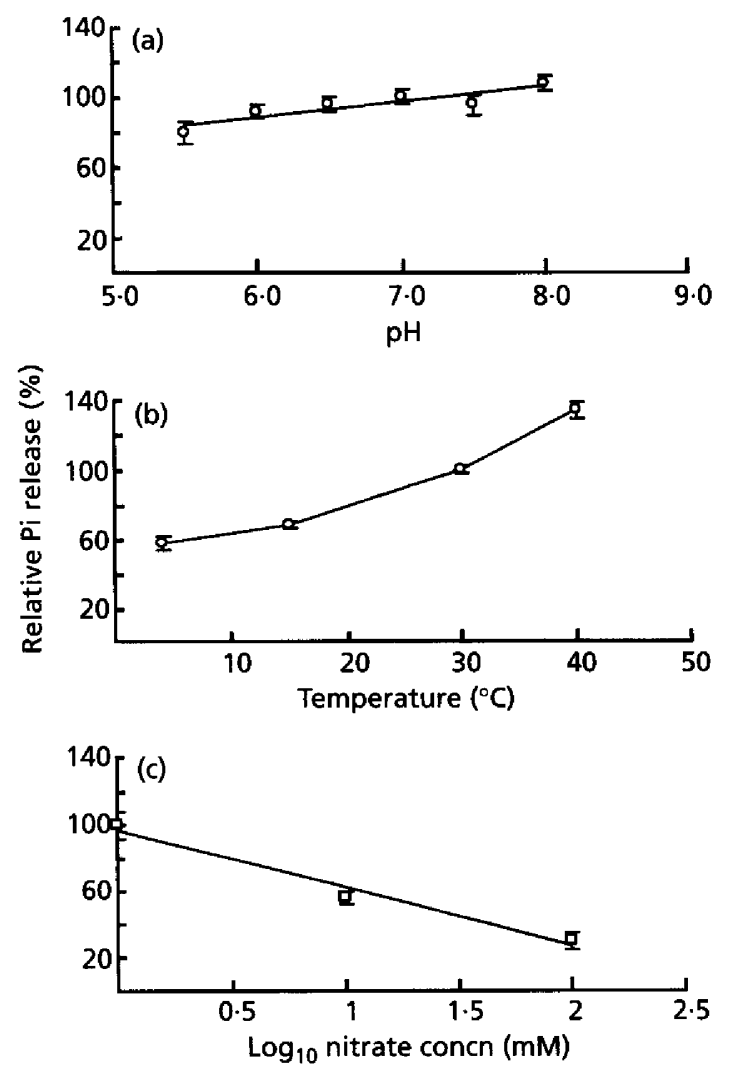

Fig. 4. The effects of (a) $\mathrm{pH}$, (b) temperature and (c) nitrate on anaerobic phosphate release by $A$. johnsonii M45. Error bars indicate SE (from three experiments). Cells were pre-grown aerobically (see Methods).

the limits of error of the control in the presence of both $0.2 \mathrm{mM}$ and $0.5 \mathrm{mM} \mathrm{Cd}^{2+}(P=0.95)$.

A decrease in the chain length of longer polyP molecules (Fractions 2 and 3 in Fig. 2c, d), resulting in the apparent transition of polyP between different pools, has been proposed by Clark et al. (1986) who found that the polyP molecules recovered during stationary phase in Propionibacterium shermanii were significantly shorter than those isolated from exponential-phase cells. It is possible that under conditions of polyP degradation (for example in Acinetobacter spp. during anaerobiosis) the progressive shortening of polyP due to enzymic hydrolysis results in an apparent flux from the pool of long-chain polyP to the short-chain pool.

The apparent difference between degradation of shortchain polyP detected by the extractive method and by ${ }^{31} \mathrm{P}-\mathrm{NMR}$ may be due to the intracellular formation of short-chain polyP (through shortening of long-chain polyP) which would be detectable by the extractive method but not by ${ }^{31} \mathrm{P}-\mathrm{NMR}$. Thus the apparent inhibition of degradation of short-chain polyP in the presence of $0.2 \mathrm{mM} \mathrm{UO}_{2}^{2+}$ (Fig. 2a, b) could result from increased flux into short-chain polyP from the longchain soluble pool during the incubation period. This would be consistent with the observed inhibition by

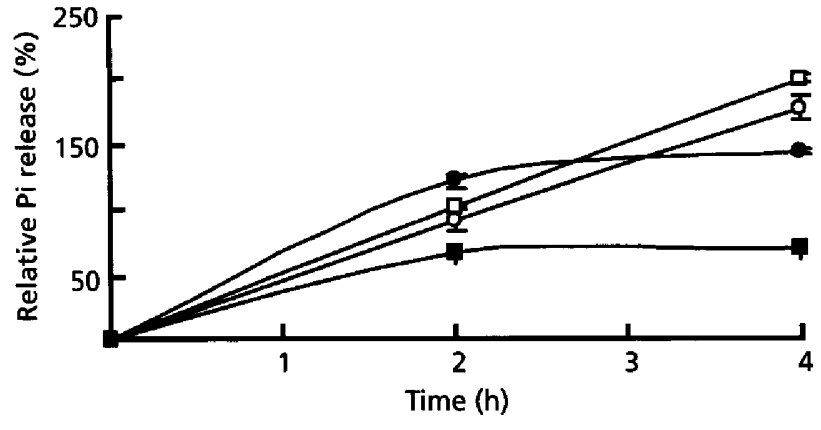

Fig. 5. The effect of aerobic pre-growth in the presence of $5.0 \mathrm{mM}$ tungstate on inhibition of phosphate release by nitrate during subsequent anoxic incubation. $\square$, no tungstate present during growth, anoxic incubation without $\mathrm{NO}_{3}^{-} ; \mathbf{\square}$, no tungstate present during growth, anoxic incubation with $10 \mathrm{mM} \mathrm{NO}-; 0,5 \mathrm{mM}$ tungstate present during growth, anoxic incubation without nitrate; $9,5 \mathrm{mM}$ tungstate present during growth, anoxic incubation with $10 \mathrm{mM} \mathrm{NO}_{3}^{-}$. $100 \% \mathrm{Pi}$ release corresponds to control cells pre-incubated without tungstate and incubated anaerobically for $2 \mathrm{~h}$. Where they are not visible, error bars ( \pm 1 SEM) are within the dimensions of the symbols.

cadmium of the mobilization of long-chain, soluble polyP (Fraction 2, Fig. 2c, d) which may be due to its inhibitory effect on the polyP-degrading enzyme(s), particularly as cadmium (but not uranium) was found to co-localize with (poly)phosphate.

Calculation of the total polyP content of cells prior to and following anaerobic incubation (Fig. 2a) showed that, overall, polyP degradation varied according to the treatment. In the case of $0.5 \mathrm{mM} \mathrm{UO}_{2}^{2+}$ there was a significant stimulatory effect on polyP degradation $(P=$ $0.95)$, whereas the presence of $\mathrm{Cd}^{2+}(0.2 \mathrm{mM})$ was inhibitory.

EDAX analysis of sections of cadmium- or uranylchallenged cells (not shown) indicated that only the former can enter the cell. This might be expected given that the entry of $\mathrm{Cd}^{2+}$ into bacterial cells via either the $\mathrm{Mn}^{2+}$ (Laddaga et al., 1985) or $\mathrm{Zn}^{2+}$ (Laddaga \& Silver, 1985) transport systems has been shown. EDAX also demonstrated that, in addition to cadmium, the electronopaque granules contained phosphorus and divalent cations, consistent with polyP granules described in other studies (Jones \& Chambers, 1975).

Aiking et al. (1984) found that whilst cells of Klebsiella aerogenes exposed to cadmium accumulated greater amounts of phosphate, they did not contain polyP granules which were present in cells not exposed to the heavy metal. A detoxification mechanism whereby cadmium precipitates with phosphate released from polyP was proposed to account for the greater sensitivity of phosphate-limited cells which did not accumulate polyP. This mechanism is consistent with the work of Keasling \& Hupf (1996) in which a genetically manipulated strain of Escherichia coli lacking exopolyphosphatase activity $\left(\mathrm{Ppx}^{-}\right)$and unable to degrade previously accumulated polyP had greater sensitivity to cadmium 
than the corresponding $\mathrm{Ppx}^{+}$strain which could. The relative sensitivity to heavy metals of A. johnsonii M45 cells lacking polyP remains to be examined.

No evidence for the entry of uranium into living bacterial cells via metabolic processes has been established; it is possible that the relatively large $\mathrm{UO}_{2}^{2+}$ oxycation does not sufficiently resemble a species for which there is a transport system. Suresh et al. (1986) propose a mechanism whereby the active uptake of $\mathrm{Cd}^{2+}$ by Acinetobacter cells stimulates the degradation of surface polyPs which provides ATP for the metal-uptake mechanism. The work of van Groenestijn et al. (1987) demonstrates that such a phenomenon is possible but evidence of stimulation of surface polyP degradation by $\mathrm{Cd}^{2+}$ was not obtained in the present study. In the case of $\mathrm{UO}_{2}^{2+}$, for which there is no evidence of cellular uptake, the coupling of metal uptake to surface-polyP (short-chain polyP) degradation is unlikely. A second mechanism should be invoked to account for the observed stimulation of polyP degradation by $\mathrm{UO}_{2}^{2+}$. The enzyme(s) responsible for polyP hydrolysis is probably regulated by the concentration of free phosphate, for example in the case of polyphosphatase (van Groenestijn et al., 1989; Vasiliadis et al., 1990; Bayly et al., 1991). A decrease in the free phosphate concentration by its precipitation with divalent cations in the periplasm or at the cell surface (Dick et al., 1995) would alleviate inhibition of the hydrolysis reaction, resulting in an increase in the observed rate and extent of polyP degradation by removal of $\mathrm{Pi}$.

Temperature, $\mathrm{pH}$ and the presence of nitrate were all found to affect anaerobic phosphate release by $A$. jobnsonii M45. The stimulatory effect of temperature on anaerobic Pi release (Fig. 4a), is probably attributable to increased activity of polyP-degrading enzyme(s). The increase in anaerobic Pi release with increasing $\mathrm{pH}$ (Fig. $4 \mathrm{~b}$ ) is in agreement with previous work. Smoulders et al. (1994a, b) found that for phosphorus-accumulating organisms in wastewater treatment, the energy requirement for carbon source (acetate) uptake increased with $\mathrm{pH}$. The proposed source of additional energy (in the form of ATP) was hydrolysis of polyP, which in turn would result in greater $\mathrm{Pi}$ release at higher $\mathrm{pH}$. In support of this, van Groenestijn et al. (1987) have demonstrated that ATP can be generated from polyP hydrolysis, leading to the release of $\mathrm{Pi}$ from cells. In studies on the phosphate transport of Acinetobacter spp., van Veen et al. (1993) found that a proton-motive force across the cytoplasmic membrane inhibited efflux of $\mathrm{Pi}$ whilst efflux increased with increasing (external) $\mathrm{pH}$.

Nitrate has been identified as a common component of municipal and industrial wastewaters, e.g. the $\mathrm{NO}_{3}^{-}$ concentration of such wastewaters may range from less than $1 \mathrm{mM}\left(62 \mathrm{mg}^{-1}\right)$ to greater than $200 \mathrm{mM}(12.4 \mathrm{~g}$ $\mathrm{I}^{-1}$ ) (Chen et al., 1996; Zhou \& Fang, 1997) whereas the nitrate concentration of uranium-bearing nuclear-fuelcycle waste may exceed $1 \mathrm{M}\left(62 \mathrm{~g} \mathrm{l}^{-1}\right)$ (Tolley, 1993). Although little work has been done on anoxic res- piration using nitrate as a terminal electron acceptor in Acinetobacter, the inhibitory effect of $\mathrm{NO}_{3}^{-}$on ' anaerobic' phosphate release in activated sludge has previously been noted (Egli \& Zehnder, 1994; Kroiss \& Negm, 1994). In mixed cultures, such inhibition is probably a result of competition from denitrifying polyP bacteria (Kerrn-Jespersen et al., 1994). No direct mechanism for the inhibition of phosphate release by nitrate has been clearly demonstrated, although Klebanoff (1993) found that nitrite had a bactericidal effect on $E$. coli, possibly through the generation of free radicals. In addition, Sijbesma et al. (1996) have demonstrated an uncoupling effect (dissipation of the proton-motive force) of nitrite on Pseudomonas fluorescens at concentrations exceeding $20 \mathrm{mM}$. Such an effect is unlikely to account for the inhibitory action of nitrate observed in the present study (Fig. 4c) as Pi efflux in Acinetobacter $\mathrm{sp}$. was stimulated by dissipation of the proton-motive force (van Veen $e$ t al., 1993). Also, the concentration of nitrite in the present experiments did not exceed $0.5 \mathrm{mM}$. Kortsee et al. (1994) have shown that nitric oxide has an inhibitory effect on phosphate release in activated sludge. Under such conditions, nitric oxide could be generated by denitrifying organisms. This would not explain the inhibitory effect of nitrate in pure culture as A. johnsonii M45 cannot denitrify completely (see above).

If the nitrate reductase of $A$. jobnsonii M45 does have a respiratory function, it is possible that in the presence of nitrate, the proton-motive force can be maintained in the absence of molecular oxygen without the need for additional energy generation via polyP degradation. van Veen et al. (1993) have shown that the presence of a proton-motive force is inhibitory to Pi efflux, which may allow nitrate reduction (to nitrite, see Results) to occur preferentially to polyP degradation.

The antagonistic effect of tungstate pre-treatment towards nitrate inhibition (Fig. 5) is likely to result from the formation of a dysfunctional nitrate reductase due to substitution of tungsten for molybdenum, which is required for the function of the enzyme (Stewart, 1988; Hemschemeier et al., 1991; Frunzke et al., 1993). This effect is consistent with the above: when energy generation through respiratory electron transport to nitrate is inhibited (Table 1), the inhibitory effect of nitrate on Pi release would be diminished.

In conclusion, analysis by two methods has shown that polyP is degraded anaerobically by A. jobnsonii M45 in the presence and absence of submillimolar concentrations of $\mathrm{Cd}^{2+}$ and $\mathrm{UO}_{2}^{2+} .{ }^{31} \mathrm{P}-\mathrm{NMR}$ indicated that $\mathrm{Pi}$ was formed at the expense of polyP under these conditions, and an extractive method to quantify polyP showed that the extent of polyP degradation was dependent on the metal used. Calculation of total polyP showed that in the presence of $0.5 \mathrm{mM} \mathrm{UO}_{2}^{2+}$ there was a stimulatory effect on overall polyP degradation. Conversely, cadmium at 0.2 and $0.5 \mathrm{mM}$ had a negative effect on the process, possibly as a result of the ability of $\mathrm{Cd}^{2+}$ to enter cells and inhibit the enzyme(s) responsible 
for polyP hydrolysis. In accordance with published data for $\mathrm{Cd}^{2+}$, the presence of $\mathrm{UO}_{2}^{2+}$ (but not, in this case, $\mathrm{Cd}^{2+}$ ) stimulated degradation of surface polyP but since $\mathrm{UO}_{2}^{2+}$ probably cannot enter the cell this is likely to be attributable to phosphate sequestration into cell-surface-bound metal phosphate (Dick et al., 1995), promoting breakdown of further polyP.

Thus, this study demonstrates that polyP degradation can occur in the presence of low concentrations of heavy metals. However, at higher metal concentrations the process of heavy metal accumulation may be limited by the toxic effects of the metal on polyP hydrolysis, particularly in the case of those metals that can enter cells. Nitrate may also be problematic and could necessitate the use of a nitrate reductase deficient $\left(\mathrm{Nar}^{-}\right)$ strain of polyP-accumulating Acinetobacter. Partial inhibition of nitrate reductase by tungstate suggested this possibility but initial attempts to obtain a $\mathrm{Nar}^{-}$ strain which could be used in the metal-accumulation process were unsuccessful due to pleiotropic effects associated with the $\mathrm{Nar}^{-}$phenotype. Possible reasons for this would require further investigation.

\section{ACKNOWLEDGEMENTS}

C.D.B. was supported by a CASE award from BNFL in conjunction with the EPSRC Clean Technology Programme (award no. 94315825). The authors would like to thank Dr H. Eccles (BNFL) for helpful discussions, Dr E. Hayes (Severn Trent Water) for assistance with isolation of the Acinetobacter sp. and Dr M. Tolley (School of Chemistry, University of Birmingham) for assistance with NMR spectroscopy.

\section{REFERENCES}

Aiking, H., Stijnman, A., van Garderen, C., van Heerikhuizen, $H$. \& van 'T Riet, J. (1984). Inorganic phosphate accumulation and cadmium detoxification in Klebsiella aerogenes NCTC 418 growing in continuous culture. Appl Environ Microbiol 47, 374-377.

Battistoni, P., Fava, G. \& Ruello, M. (1993). Heavy metal shock load in activated sludge uptake and toxic effects. Water Res 27 , 821-827.

Bayly, R. C., Duncan, A., May, J. W., Schembri, M., Semertjis, A., Vasiliadis, G. \& Raper, W. G. C. (1991). Microbiological and genetic aspects of the synthesis of polyphosphate by strains of Acinetobacter. Water Sci Technol 23, 747-754.

Beacham, A. M., Seviour, R. J. \& Lindrea, K. C. (1992). Polyphosphate-accumulating abilities of Acinetobacter isolates from activated sludge. Water Res 26, 121-122.

Bond, P., Hugenholtz, P., Keller, J. \& Blackall, L. (1995). Bacterial community structures of phosphate-removing and non-phosphate-removing activated sludges from sequencing batch reactors. Appl Environ Microbiol 61, 1910-1916.

Boswell, C. D., Hewitt, C. J. \& Macaskie, L. E. (1998). An application of bacterial flow cytometry-evaluation of the toxic effects of four heavy metals on Acinetobacter sp. with potential for bioremediation of contaminated wastewaters. Biotechnol Lett 20, 857-863.

Chen, S., Chen, C., Shen, Y., Chiu, C. \& Cheng, H. (1996). The treatment of high-strength nitrate waste-water by biological methods - operational characteristics study. Water Sci Technol 34, 269-276.

Christensson, M., Blackall, L. L. \& Welander, T. (1998). Metabolic transformations and characterisation of the sludge community in an enhanced biological phosphorus removal system. Appl Microbiol Biotechnol 49, 226-234.

Clark, J. E., Beegen, H. \& Wood, H. J. (1986). Isolation of intact chains of polyphosphate from 'Propionibacterium shermanii' grown on glucose or lactate. J Bacteriol 168, 1212-1219.

Dick, R. E., Boswell, C. D. \& Macaskie, L. E. (1995). Uranyl phosphate accumulation by Acinetobacter spp. In Biobydrometallurgical Processing, pp. 299-306. Proceedings of the International Conference on Biohydrometallurgical Processing, Viña del Mar, Chile. Edited by T. Vargas, H. Toledo \& J. V. Wiertz. Santiago: The University of Chile.

Egli, T. \& Zehnder, A. J. B. (1994). Phosphate and nitrate removal. Curr Opin Biotechnol 5, 275-284.

Fuhs, G. W. \& Chen, M. (1975). Microbiological basis of phosphate removal in the activated sludge process for the treatment of wastewater. Microb Ecol 2, 119-138.

Frunzke, K., Heiss, B., Meyer, O. \& Zumft, W. (1993). Molybdopterin guanine dinucleotide is the organic moiety of the molybdenum cofactor in respiratory nitrate reductase from Pseudomonas stutzeri. FEMS Microbiol Lett 113, 241-246.

van Groenestijn, J. W. \& Deinema, M. H. (1985). Effects of cultural conditions on the accumulation and release of phosphate by Acinetobacter strain 210A. In Proceedings of the International Conference Management Strategies, Phosphorus in the Environment, pp. 405-410. Edited by J. N. Lester \& P. W. Kirk. London: Selper.

van Groenestijn, J. W., Deinema, M. H. \& Zehnder, A. J. B. (1987). ATP production from polyphosphate in Acinetobacter strain 210A. Arch Microbiol 148, 14-19.

van Groenestijn, J. W., Bentvelsen, M. M., Deinema, M. H. \& Zehnder, A. J. B. (1989). Polyphosphate-degrading enzymes in Acinetobacter spp. and activated sludge. Appl Environ Microbiol 55, 219-223.

Gurr, G. T. (editor) (1963). Biological Staining Methods. London: George T. Gurr.

Hemschemeier, S., Grund, M., Keuntje, B. \& Eichenlaub, R. (1991). Isolation of Escherichia coli mutants defective in uptake of molybdate. J Bacteriol 173, 6499-6506.

Jones, H. \& Chambers, L. (1975). Localized intracellular polyphosphate formation by Desulfovibrio gigas. J Gen Microbiol 89, $67-72$.

Keasling, J. D. \& Hupf, G. A. (1996). Genetic manipulation of polyphosphate metabolism affects cadmium tolerance in Escherichia coli. Appl Environ Microbiol 62, 743-746.

Kerrn-Jespersen, J., Henze, M. \& Strube, R. (1994). Biological phosphorus release and uptake under alternating anaerobic and anoxic conditions in a fixed-film reactor. Water Res 28, 1253-1255.

Klebanoff, S. (1993). Reactive nitrogen intermediates and antimicrobial activity-Role of nitrite. Free Rad Biol Med 14, 351-360.

Kornberg, A. (1995). Inorganic polyphosphate: toward making a forgotten polymer unforgettable. J Bacteriol 177, 491-496.

Kortsee, G. J. J., Appeldoorn, K. J., Bonting, C. F. C., Van Niel, E. W. J. \& van Veen, H.W. (1994). Biology of polyphosphateaccumulating bacteria involved in enhanced biological phosphorus removal. FEMS Microbiol Rev 15, 137-153. 
Kroiss, H. \& Negm, M. (1994). The effect of nitrate and treatment process on phosphate release in batch gravity thickener. Water Res 28, 2209-2217.

Laddaga, R. A. \& Silver, S. (1985). Cadmium uptake in Escherichia coli K12. J Bacteriol 162, 1100-1105.

Laddaga, R. A., Bessen, R. \& Silver, S. (1985). Cadmium-restricted mutant of Bacillus subtilis 168 with reduced cadmium transport. J Bacteriol 162, 1106-1110.

Pascal, M.-C., Burini, J.-F., Ratouchniak, J. \& Chippaux, M. (1982). Regulation of the nitrate reductase operon: effect of mutations in chlA, B, D and E genes. Mol Gen Genet 188, 103-106.

Pierpoint, W. S. (1957). The phosphatase and meta-phosphatase activities of pea extracts. Biochem $J 65,67-76$.

Rao, N., Roberts, M. \& Torriani, A. (1985). Amount and chain length of polyphosphates in Escherichia coli depend on growth conditions. J Bacteriol 162, 242-247.

Sijbesma, W., Almeida, J., Reis, M. \& Santos, H. (1996). Uncoupling effect of nitrite during denitrification by Pseudomonas fuorescens - an in vivo ${ }^{31}$ P-NMR study. Biotechnol Bioeng 52, 176-182.

Smolders, G. J., van Loosdrecht, M. C. \& Heinjen, J. J. (1994a). pH - key factor in the biological phosphorus removal process. Water Sci Technol 29, 71-74.

Smolders, G. J. F., Van Der Meij, J., Van Loosdrecht, M. C. M. \& Heijnen, J. J. (1994b). Model of the anaerobic metabolism of the biological phosphorus removal process: stoichiometry and $\mathrm{pH}$ influence. Biotechnol Bioeng 43, 461-470.

Stewart, V. (1988). Nitrate respiration in relation to facultative metabolism in Enterobacteria. Microbiol Rev 52, 190-232.

Suresh, N., Roberts, M. F., Coccia, M., Chikarmane, H. M. \& Halvorson, H. O. (1986). Cadmium-induced loss of surface polyphosphate in Acinetobacter lwoffii. FEMS Microbiol Lett 36, 91-94.

Tjissen, J. P. F. \& van Steveninck, J. (1984). Detection of a yeast polyphosphate fraction localized outside the plasma membrane by the method of 31-phosphorus nuclear magnetic resonance. Biochem Biophys Res Commun 119, 447-451.

Tolley, M. R. (1993). The biological treatment of liquid wastes containing heavy metals. $\mathrm{PhD}$ thesis, University of Oxford.

Tomsett, A. B. \& Garrett, R. H. (1980). The isolation and characterization of mutants defective in nitrate assimilation in Neurospora crassa. Genetics 95, 649-660.

Towner, K. J., Bergogne-Berezin, E. \& Fewson, C. A. (editors) (1991). The Biology of Acinetobacter: Taxonomy, Molecular Biology, Physiology, and Industrial Relevance. New York: Plenum.

Vasiliadis, G., Duncan, A., Bayly, R. C. \& May, J. W. (1990). Polyphosphate production by strains of Acinetobacter. FEMS Microbiol Lett 70, 37-40.

van Veen, H. W., Abee, T., Kortsee, G. J. J., Konings, W. N. \& Zehnder, A. J. B. (1993). Mechanism and energetics of the secondary phosphate transport system of Acinetobacter jobnsonii 210a. J Biol Chem 268, 19377-19383.

Wagner, M., Amann, R., Lemmer, H., Manz, W. \& Shleifer, K. (1994a). Probing activated sludge with fluorescently labeled rRNA-targeted oligonucleotides. Water Sci Technol 29, 15-23.

Wagner, M., Erhart, R., Manz, W., Amann, R., Lemmer, H., Wedi, D. \& Schleifer, K. (1994b). Development of an rRNA-targeted oligonucleotide probe specific for the genus Acinetobacter and its application for in situ monitoring in activated sludge. Appl Environ Microbiol 60, 792-800.

Zhou, G. \& Fang, H. (1997). Anoxic treatment of low-strength wastewater by immobilized sludge. Water Sci Technol 36, 135-141.

Received 17 November 1998; revised 1 February 1999; accepted 22 February 1999. 